\title{
How Does Tourism Affect Protected Areas?: A Multi-Criteria Decision Making Application in UNESCO Natural Heritage Sites
}

\author{
Onur Selçuk \\ Akdeniz University Faculty of Tourism https://orcid.org/0000-0003-2818-2291 \\ Hatice KARAKAS \\ Akdeniz University Faculty of Tourism \\ Beykan CIZEL \\ Akdeniz University Faculty of Tourism \\ Emre Ipekci Cetin ( $\square$ ecetin@akdeniz.edu.tr) \\ Akdeniz Universitesi Iktisadi ve Idari Bilimler Fakultesi https://orcid.org/0000-0002-8108-1919
}

\section{Research Article}

Keywords: Natural Heritage Sites, UNESCO Convention, Protected areas, MCDM, Tourism affects

Posted Date: January 3rd, 2022

DOI: https://doi.org/10.21203/rs.3.rs-1142120/v1

License: (c) (7) This work is licensed under a Creative Commons Attribution 4.0 International License. Read Full License 


\section{Abstract}

The tourism is an industry that makes extensive use of natural heritage sites. It has long been debated whether tourism is a threat to natural heritage sites. This research has been written to contribute to these discussions. In the study, the author(s) aims to determine the effects and threat levels of tourism in World Natural Heritage Sites. Within the scope of the research, the impact of tourism on 24 samples selected from UNESCO natural heritage sites was examined with multi-criteria decision-making methods. According to the results of the research, the highest endangerment level among the selected NHS are "Lake Malawi National Park", "Machu Picchu Historic Sanctuary" and "Phong NhaKe Bang National Park", while "Atlantic Forest Southeast Reserves", "Sinharaja Forest Conservation Area" and "Vredefort Dome" were found to be the least affected sites. The research results were discussed with the implications developed in accordance with the contexts of the selected NHS.

\section{Introduction}

World Heritage Sites (WHS), which have become very popular nowadays, are recognized as the most efficient international legal scroll for the protection of natural and cultural heritage (Strasser 2002). However, the areas included in the WHS list can become destinations for tourism development. Many world heritage sites are important attractions for nature and cultural tourism. Based on their natural, geographical, cultural and historical features natural and cultural heritage assets form the tourism destination components (Formica and Uysal 2006), playing an important role as attractive factors in terms of tourist flows (Buckley 2018) and competitiveness (Crouch 2011). World Heritage status motivates tourists to experience the site (Bryce et al. 2015). Indeed, for tourism researchers, the WHS' list is particularly notable for its capability of being "magnet for visitors" (Fyall and Rakic 2006). The image created by WHS status is seen as the "best brand" image that provides a competitive advantage over unlisted destinations (Buckley 2004). However, despite the impacts of WHS on tourism sector, studies examining the relationship between tourism activities and WHS status differ significantly (Yang et al. 2010; Cellini 2011). While some quantitative studies have found a positive impact (Yang et al. 2010), others have highlighted a negligible association (Cuccia et al. 2016). Regarding this issue, UNESCO and IUCN did not remain indifferent to the possible negative effects of tourism on natural areas and included them in their reports. Accordingly, in the World Heritage Convention tourist development projects and tourism and recreation areas are listed as possible risks in the protection of heritage sites (WHC 2021). In this context, it is important to reveal the environmental status of the natural heritage areas where tourism activities take place or to determine the level of danger. When the literature is examined, few studies evaluate the situation of the natural areas in UNESCO's WHS. To the best of author(s)' knowledge, this study can be considered as the first study to include heritage sites where tourism is seen as a proven danger element through UNESCO data.

In this context, the research questions of the study are: "Is tourism really a threat to natural heritage sites?", and "How does tourism affect natural heritage sites?". Therefore, aim is to ascertain the effects and threat levels of tourism in natural heritage sites within WHS. Accordingly, there was an attempt to determine the areas with the potential to fall to the critical hazard level. In addition, author(s) aspire to inform the international community about the conditions that threaten WHS (significant concern) and to encourage corrective action. The popularity of natural attractions and the high potential of nature-based tourism have been effective in the selection of natural heritage sites as the study area. In the continuation, first the World Heritage Convention (WHC) is explained together with the effects of tourism on natural heritage sites. This is followed by elaboration on multi-criteria decision-making techniques in the method part and finalized with interpretations of the findings.

\section{World Heritage Convention}

UNESCO's WHC is recognized as the foremost instrument of conservation to recognize and preserve humanity's outstanding natural and cultural heritage for posterity. While the cultural and natural heritage sites were initially evaluated separately, after the adoption of the Convention for the Protection of the World Cultural and Natural Heritage at the 1972 UNESCO General Conference these started to be evaluated together. The convention addresses issues such as the protection of cultural and natural heritage, biodiversity, endangered species, natural habitats and climate (Matsuura 2007). 194 countries have approved the convention as of 2020 (UNESCO 2021a). As of June 2021, there are 1121 heritage sites in the World Heritage List (WHL), including 213 natural,869 cultural, and 39 mixed sites (WHC 2021).

Although the issue of protection of heritage sites was handled in good faith in the beginning, there are serious discussions about the selection of heritage lists and the determination of areas over time. For instance, Bolla (2005) questioned whether this increscent size of the list would have the effect of devaluing the site and probably attenuating the World Heritage label. Observers of World Heritage Committee, such as Meskell (2011) and Cameron (2013) have expressed various levels of concern about the current situation. Researchers point to system overload as it grows without concomitant growth in resource and conservation capacity, and they are concerned about the possible loss of credibility of the WHL due to perceptions of increasing politicization of decisions. There are also controversial aspects, such as site 
selection, which is not only the subject of rent seeking due to national interests pursued by bureaucrats and politicians, but also by the commercial heritage industry (Frey and Steiner 2011). Moreover, less protection of areas that are not part of the WHL, the potential degradation of areas due to over tourism, and the creation of an attractive target for terrorist attacks are among the topics of discussion.

\subsection{UNESCO Selection Criterions for Natural Heritage Sites}

Seen as an "innovative legal instrument", the Convention, is designed to enable nations to cooperate in the protection of cultural and natural areas of extraordinary value to humanity (Hall 2008). The main purpose of the nomination process at international level is "inclusion of a property on the WHL in order to provide additional protection to the site" (Slatyer 1983). The inclusion of candidates who do not meet the standards is considered to devalue the purpose of the Convention and the protection it provides to the world's cultural and natural heritage. In addition to the prestige conferred on a WHS, it creates some degree of protection under international law and a possible increase in the attractiveness of the site as a tourism destination. Areas degraded by human action or natural causes may be deleted from the heritage list and added to the World Heritage in Danger List. The purpose of placing an area on the endangered list is to increase the likelihood of recovery for the site. Thus, it is aimed to draw attention to the heritage site before the 'symbolic fate' of deregistration takes place. WHS can be classified as cultural, natural, or mixed sites, depending on what criteria they meet. As of 2005, WHS have been selected based on six cultural and four natural criteria. With the adoption of renewed operational guidelines for the fulfilment of the WHC, aforementioned ten criteria are on UNESCO webpage (UNESCO 2021b). To get included in the WHL, natural sites must have outstanding universal value and measure up at least one of these selection criteria.

\section{Tourism As Ascertained Danger}

Tourism and its effects on the environment were not foreseen in the 1972 Convention and were only included as a concept in the Recommendation. Today, however, tourism poses both an opportunity and a threat to UNESCO WHS. Recognition of a heritage site by UNESCO often helps the destination reinvent itself, innovate, and improve the resources and products devoted to tourism. However, the destination itself may not have an adequate or updated tourism management plan that considers the changes brought about by the UNESCO recognition. It can also create tension when tourism leads to site abuse, commodification, increased waste and resource exploitation (De Ascaniis et al. 2018). Although WHL accreditation means identifying, recognizing, and protecting natural hotspots of global value, WHL is now widely admitted as a marketing tool for tourism campaigns and strong support for attracting tourism (Huang et al. 2012). Placing on the list is conspicuous to policy makers as it makes the site stand out and enhances its attractiveness (Frey and Steiner 2011), resulting in generated income. Recently, the tourism literature has begun to realize the prepotent effectiveness of UNESCO recognition in increasing the attractiveness of tourism, without conclusive results (Yang et al. 2010; Su and Lin 2014; Patuelli et al. 2016). As a result, there has been a long-standing debate between heritage preservation and tourism development, as experts in various disciplines have expressed concerns about potential damage caused by over tourism to such sites(Yang and Lin 2014). This discussion has crucial importance, considering the relationship between sustainable planning, tourism, and heritage protection.

The sustainable tourism practices are now a necessity for the growth of tourism industry in heritage sites (UNESCO 2021c). Indeed, since 1994, sustainability has been increasingly integrated into the directions recommended by the WHC (Marcotte and Bourdeau 2012). Donations and support funds have been collected for many of the listed heritage sites. Protected area managers and conservationists around the world spend sizeable amount of money each year to conserve biodiversity (Castro and Locker 2000). However, these donations are often in serious conflict with the socioeconomic development needs of local residents (McNeely and Ness 1996).

The reason why some of the protected areas do not function well, despite sufficient management, may be mainly because of intensified human spatial use in the protected areas, causing changes in biodiversity and ecological function. Satellite-based analyzes reveal that intensive land use and human populations have swiftly increased in recent years around many protected areas (Hansen et al., 2013). Besides, the habitat destruction is a key component of species extinction (Bibby 1994; Brooks et al. 2002), with human activities being (Kozak 2013)responsible for the vast majority of existing habitat loss (Bawa and Dayanandan 1997). At this point, the size of the protected area is important in terms of the volume and functionality of the conservation activities due to the negative effects of tourism Parks and Harcourt (2002) note that small reserves are particularly prone to this effect, and conservation agencies are increasingly focusing on such areas.

Environmental impacts of tourism in heritage sites include ecosystem, season, management measures, tourist behavior and characteristics, scale and intensity of tourism operations (Buckley 2012, 2018; Koichi et al. 2013). Flora effects vary from botanical differences to usage type in the site. Forest floor plants are usually less tolerant to crush resistance, while open grassy habitats are harder. 
Impacts on ground often include erosion and compaction. Tourism usually causes soil compaction because of recreational activities. This raises runoff from snow and rain, resulting in decreased water absorption, erosion, and vegetation loss. Soil compaction is inevitable but may be limited to certain areas. Turbidity in source is a frequent consequence of recreation activities and tourism infrastructure. Tourist activities are more likely to alter water quality in ways that harm aquatic flora and fauna if soils are more prone to erosion. The absence or malfunction of the sewerage and cesspool systems in the hotels can drive tourists away from the region. Organic waste from poorly treated sewage affects water quality. On coastlines, these wastes may cause pollution (Pedersen 2002).

Disturbances from wildlife watching affect some species more than others. Distinct species develop a tolerance for discomfort after an initial impact. The habit can be mistakenly viewed as favorable, as it draws visitors up to wildlife. But it can pose a problem: habitual wildlife can be in search for food, and they may injure or even kill visitors. When the tolerance levels of nesting birds are exceeded, they could leave their nests. Timid species permanently replace the recreation areas when they encounter visitors, while others such as deer may get used to it over time. However, some species are readily frightened than others, and even any simple factor can influence their breeding and feeding patterns (Pedersen 2002).

Despite the high level of protection provided to natural heritage sites, the balance of protection and use has deteriorated due to the negative effects of the above-mentioned tourism activities. Exotic species are increasingly infesting protected areas (Stohlgren and Schnase 2006) and some native species have become extinct in protected areas. (Brashares et al. 2001). These extinctions are often attributed to the isolation of nature reserves (Wilcove and May 1986). In addition, tourism activities sometimes rise near the boundaries of protected areas and can replace wildlife (Hansen and DeFries 2007). In order to prevent this situation and to develop conservation activities, it has been proposed to create buffer zones around the protected areas (Noss 1983).

\subsection{Carrying Capacity and Related Issues}

Carrying capacity is introduced as a conceptual tool for managing tourism pressures in heritage sites. For heritage sites, the carrying capacity is expressed as 'the number of people who visit the site without causing irreversible damage to its natural and built environment and without degrading the quality of the visitor's experience' (Jinshi 2014). Carrying capacity can serve as a frame of reference for a variety of purposes, depending on the characteristics of the site (size, site characteristics, community, tourism, and visitors) and the adoption capacities of the local system (institutional, economic, social, and cultural) and implementing visitor management policies. Carrying capacity should be evaluated in the context of heritage site and/or destination management plans. Tourism management and careful planning, as well as respect for the well-being of destination's permanent residents, are other issues that both researchers and managers must constantly consider (Wall 2020). Discussions about human pressure on resources go long way back, but in the tourism context, research focusing on carrying capacity in North American national parks is in lead (Dodds and Butler 2019).

The negative effects of tourism occur when the environment exceeds the limit of coping with tourism activity within the limits of acceptable change. Uncontrolled tourism poses potential threats especially to the sustainability of natural areas. In recent years, because of tourism mishandling and profit maximizing policies, many tourist areas and local communities and the wildlife have suffered from tourist concentrations. For this reason, over tourism (Seraphin et al. 2018; Cheung and Li 2019) leads to the failure of existing policies that promote tourism, continuous and increased cultural site destructions, natural heritage degradation, and harm to local communities. Tourism is being studied as an important topic of conservation and management as it is probably the most important commercial use for protected natural areas (Spenceley 2018). However, ignoring environmental concerns in tourism development in heritage (natural) areas is a factor that will threaten sustainability (Badola et al. 2018).

Post-organized infrastructure construction in natural heritage sites initiates a complex process chain that is often unfeasible to reverse. Infrastructure has a variety of indirect and direct ecological impacts on the environmental areas with a spatial extent through to several kilometers (Ibisch et al. 2016; Tverijonaite et al. 2018). Better access to natural area destinations not only impacts its immediate surroundings along the way; but it also affects satisfaction among visitors, as well-organized roads result in higher visitor traffic. This could cause an increased demand for more service development and infrastructure (Haraldsson and Ólafsdóttir 2018). While visitors prefer to relax in a natural and unspoiled environment, they are probably disappointed if the infrastructure and crowd level at a particular nature destination are too high. This paradox shows the importance of protection- use balance.

Ecotourism can procure an additional economic ground for the conservation of biodiversity and natural areas. Also, it has been seen as a sustainability tool, especially for developing countries where resources for environmental management are limited or non-existent (de Oliveira Silva et al. 2005). Protected areas need more flexible ownership structures and funds to improve monitoring systems and achieve equity and efficiency through nature-based tourism (Su and Xiao 2009). To ensure sustainability, it is necessary to consider scientific and empirical evidence, and also to make decisions by integrating cultural, social and political factors (Xu et al. 2014). Protection and 
management can be achieved with a balance in supporting local communities while preserving the characteristics of the natural area that allows for such tourism development (Bello et al. 2016; Lucrezi et al. 2017). Considering the visitation and environmental pressures in protected areas (Rodríguez-Rodríguez 2012), there is a need for continuous update and follow-up on conservation and management for response framework and an optimal visitor impact assessment.

\section{Method}

Multi-criteria decision-making (MCDM) techniques are designed to select among alternatives, classify these into fewer categories, or rank alternatives. MCDM is the general name of all the methods that exist to help people make decisions based on their preferences when there is more than one conflicting criterion (Mardani et al. 2015). Related techniques offer the opportunity to be used in many areas in the form of hybrid models in which more than one technique is used alone or together. Accordingly, there are studies in the literature that examined the relations of protected areas with various subjects with MCDM methods. For example, Rocchi et al. (2020) analyze the opportunities of Nature-based tourism development in Umbria, Italy, with the application of spatial multi-criteria analysis. Wang and Du (2016) use the GISbased MCDM analysis to assess the priority area for monitoring in Bogda, China. Demir (2019) explored the natural and cultural landscape values of the Mary Valley (Trabzon, Turkey) by using MCDM methods with GIS. Moreover, Valagussa et al. (2021) used multi-criteria risk analysis in their project JPI-CH PROTHEGO to identify and rank the most critical UNESCO World Heritage Sites in Europe. Kuncova et al. (2018) used TOPSIS to compare the 14 Czech regions from the tourism infrastructure using 22 criteria. Hategekimana et al. (2018), developed a multi-criteria analysis framework for determining flood hazard index using fuzzy-AHP, geographic information system, and bivariate statistics-based methods. They tested the index in some provinces of Kenya. Similarly, Semeraro et al. (2016) developed a multicriteria analysis based on Fuzzy Expert System integrated in a GIS environment to identify and map potential "hotspots" of fire vulnerability. They applied the approach in the Torre Guaceto, southern Italy. Overall, with the best of authors' knowledge, the current study can be considered as the first one to include all heritage sites where tourism is seen as a proven danger element based on UNESCO data.

In this study, natural areas that are in the list of UNESCO's natural heritage sites at the level of significant concern and where tourism activities are seen as a threat were discussed. MCDM techniques were used to rank these natural areas according to their hazard levels. 24 natural areas and 12 criteria that are thought to damage these natural areas were taken into consideration. We used the CRITIC method to determine the importance levels of the criteria, and the TOPSIS, MOORA and VIKOR methods to rank the threatened habitats according to these criteria. Rankings obtained using three different methods in an integrated manner, with the BORDA technique, were evaluated and the final ranking was reached.

The research process chart with its general stages is presented in Figure 1. In the continuation, the alternatives covered in the study (natural heritage areas affected by tourism activities) and the process of determining the criteria that are thought to affect the danger level of natural areas are explained followed by, information on data collection process and definition of the techniques used in the analysis part.

\subsection{Study area (Determination of alternatives)}

In the scope of the current study, UNESCO's World Natural Heritage List was used to determine the natural areas affected by tourism activities. Natural sites on the list were studied using the UNESCO website and the IUCN World Heritage Outlook website. The UNESCO page includes definition of the areas, their location on the map, their indicators, and documents, while the IUCN page includes reports describing the conservation status of the area. We followed A and B notations in determining the heritage sites.

= (UNESCO / Culture / World Heritage Centre / The List / World Heritage List / Advanced / Category / Natural) (A)

$=($ IUCN / Explore Sites / Advanced Search / FILTRES / Threat / Residential and Commercial Development /Tourism-Recreation Areas) (B)

With the B notation, 60 out of 213 natural heritage areas where tourism is seen as a threat were determined. Among 60 heritage sites, 24 of these with Conservation Outlook level of "Significant Concern" were selected as the final research area (alternatives) (Table 1). Rationale for selecting this level is to determine areas close to the "Critical" level limit and to make evaluations about these. 
Table 1. Alternatives and their locations

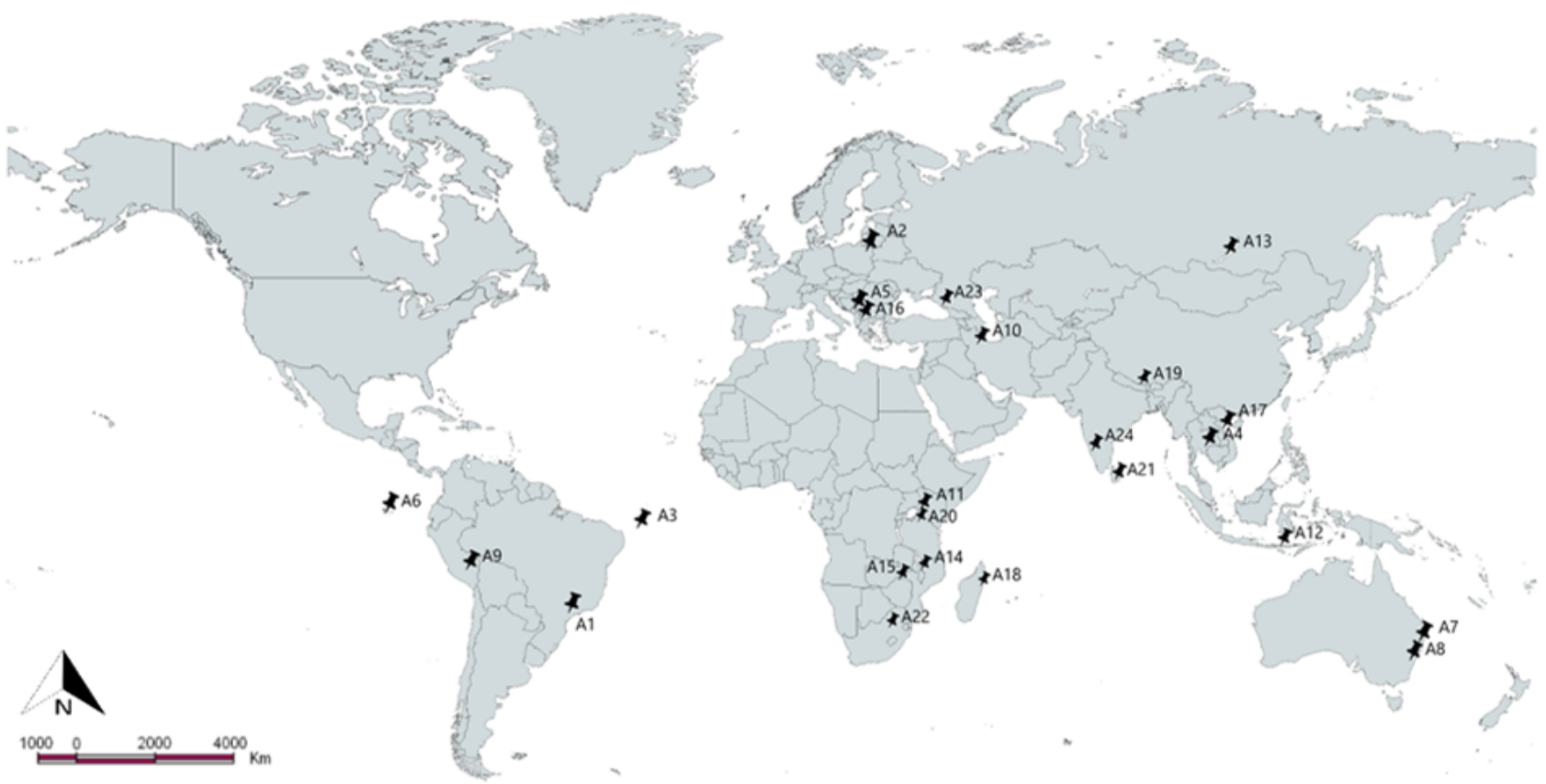

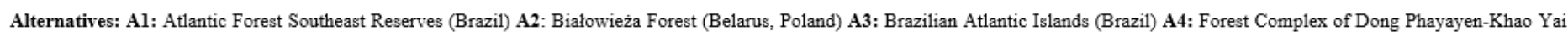

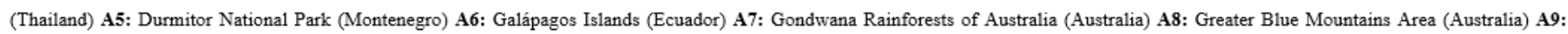

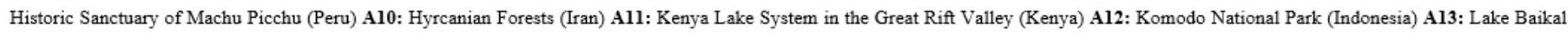

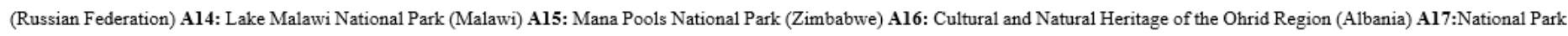

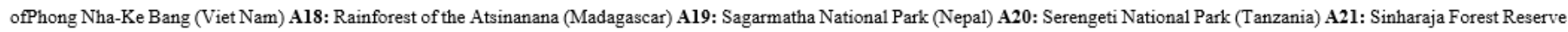
(Sri Lanka) A22: Vredefort Dome (South Africa) A23: Western Caucasus (Russian Federation) A24: Western Ghats (India)

\subsection{Determination of criterion}

Criteria were determined according to the factors that characterize the natural heritage negatively affected by tourism activities as previously mentioned in the literature. In this context, the following tourism-related criteria were discussed: the number of visitors and accommodation facilities, the impact of tourism, the impact of tourism on infrastructure, and tourism and visitor management. Regarding the carrying capacity, the size of the area and the number of species in the flora and fauna were selected as criteria. Regarding the protection and management, the year of registration in the UNESCO list, the financial aids, the report score and the general evaluation of threats in the area were taken as criteria. Criteria definitions and targeted direction in determining the threat level of criterion value are presented in Table 2.

Table 2. Definition of Criterions 


\begin{tabular}{|c|c|c|}
\hline Criterio Name & Definition & Expectation \\
\hline Property & Size of the area in hectares. & Minimum \\
\hline Date of Inscription & How many years have it been on the UNESCO heritage list? & Maximum \\
\hline Assistance & Total donations and assistances for the site (USD dollar). & Maximum \\
\hline $\begin{array}{l}\text { Reporting Trend } \\
\text { Point }\end{array}$ & Score showing the danger level of the area received in the evaluation report submitted to UNESCO. & Maximum \\
\hline Biodiversity Fauna & Number of fauna species living in the area. & Maximum \\
\hline Biodiversity Flora & Number of flora species living in the area. & Maximum \\
\hline Number of visitors & The current number of people who visited the site recently. & Maximum \\
\hline Accommodation & The number of accommodation facilities within $50 \mathrm{~km}$ of the area. & Maximum \\
\hline Impact of tourism & $\begin{array}{l}\text { Level of assessment of tourism impact included in the UNESCO conservation report (Very Low Threat, } \\
\text { Low Threat, High Threat, Very High Threat). }\end{array}$ & Maximum \\
\hline $\begin{array}{l}\text { Infrastructure in } \\
\text { the buffer zones }\end{array}$ & $\begin{array}{l}\text { Level of assessment of the impact of tourism on infrastructure in the UNESCO conservation report (Very } \\
\text { Low Threat, Low Threat, High Threat, Very High Threat). }\end{array}$ & Maximum \\
\hline $\begin{array}{l}\text { Overall } \\
\text { assessment for } \\
\text { threats }\end{array}$ & $\begin{array}{l}\text { Overall assessment level of threats in the UNESCO conservation report (Very Low Threat, Low Threat, } \\
\text { High Threat, Very High Threat). }\end{array}$ & Maximum \\
\hline $\begin{array}{l}\text { Tourism and } \\
\text { visitation } \\
\text { management }\end{array}$ & $\begin{array}{l}\text { The level of assessment of the tourism and visitation management status of the area included in the } \\
\text { UNESCO conservation report (Serious Concern, Some Concern, Mostly Effective, Highly Effective) }\end{array}$ & Minimum \\
\hline
\end{tabular}

\section{Data collection process}

Secondary data were used to collect data on alternatives and criteria. Area size, year of registration to the heritage list, aids made, number of flora and fauna species showing biodiversity in the area, data on the World Heritage Committee's report score criteria, "Description", "Indicators" and "Assistance" available on each site's own page on UNESCO's website were obtained from the values presented under the headings (WHC 2021). Values for tourism impact, infrastructure in buffer zones, overall assessment of threats, and assessment criteria for tourism and visitor management were obtained from the Conservation Outlook report available for each area on the IUCN website (IUCN 2021).Assessments presented in the report regarding the relevant criteria as "Very Low Threat, Low Threat, High Threat, Very High Threat" or "Serious Concern, Some Concern, Mostly Effective, Highly Effective" were converted into numerical data as "1,2,3,4" respectively Finally, although the number of visitors and accommodation facilities were mentioned in the reports, these were collected separately due to the lack of clear numerical data. For the number of visitors, the 2020 tourism statistics of the country where the area is located were examined. Number of accommodation facilities was obtained by counting the facilities within $50 \mathrm{~km}$ of the area via TripAdvisor and Google Map. Data obtained at the end of the data collection process, which are also evaluated as the decision matrix (X), are given in Table 3. 
Table 3

Decision matrix for natural sites

\begin{tabular}{|c|c|c|c|c|c|c|c|c|c|c|c|c|}
\hline $\begin{array}{l}\text { Criterions } \\
\text { Altemative }\end{array}$ & $C 1$ & $C 2$ & $C 3$ & $c 4$ & $C 5$ & C6 & $C 7$ & $C 8$ & $C 9$ & $C 10$ & $C 11$ & $C 12$ \\
\hline A1 & 468193 & 22 & 0 & 0 & 470 & 450 & 1300000 & 18 & 2 & 3 & 3 & 3 \\
\hline A2 & 141885 & 29 & 0 & 50 & 329 & 3363 & 150000 & 88 & 2 & 1 & 3 & 3 \\
\hline A3 & 43270 & 20 & 6000 & 0 & 178 & 400 & 106000 & 341 & 3 & 3 & 3 & 2 \\
\hline A4 & 615500 & 16 & 0 & 60 & 805 & 2500 & 700000 & 156 & 2 & 2 & 3 & 2 \\
\hline A5 & 32100 & 41 & 117000 & 23 & 300 & 700 & 270000 & 273 & 4 & 3 & 3 & 2 \\
\hline A6 & 14066514 & 43 & 627825 & 58 & 3014 & 500 & 271238 & 312 & 3 & 3 & 3 & 2 \\
\hline A7 & 370000 & 35 & 0 & 0 & 505 & 1625 & 2000000 & 218 & 2 & 2 & 3 & 3 \\
\hline A8 & 1032649 & 21 & 0 & 13 & 416 & 1500 & 3000000 & 514 & 2 & 1 & 3 & 3 \\
\hline A9 & 38161 & 38 & 166625 & 62 & 623 & 438 & 1578030 & 289 & 2 & 3 & 3 & 2 \\
\hline A10 & 129485 & 2 & 0 & 0 & 238 & 3200 & 26000 & 232 & 3 & 3 & 3 & 2 \\
\hline A11 & 32034 & 10 & 45000 & 36 & 570 & 556 & 300000 & 1305 & 2 & 1 & 4 & 3 \\
\hline A12 & 219322 & 30 & 119500 & 0 & 1409 & 102 & 150000 & 158 & 3 & 1 & 3 & 1 \\
\hline A13 & 8800000 & 25 & 33200 & 80 & 3071 & 1800 & 2000000 & 551 & 3 & 3 & 4 & 1 \\
\hline A14 & 9400 & 37 & 147423 & 36 & 1024 & 6000 & 871000 & 34 & 3 & 3 & 4 & 1 \\
\hline A15 & 676600 & 37 & 81854 & 40 & 357 & 106 & 7500 & 14 & 2 & 3 & 3 & 2 \\
\hline A16 & 94729 & 42 & 20000 & 40 & 247 & 58 & 275000 & 154 & 3 & 3 & 4 & 1 \\
\hline A17 & 123326 & 18 & 29240 & 36 & 896 & 2700 & 4000000 & 71 & 4 & 3 & 3 & 1 \\
\hline A18 & 409661 & 14 & 155000 & 79 & 498 & 4509 & 25000 & 62 & 1 & 1 & 3 & 3 \\
\hline A19 & 124400 & 42 & 232097 & 45 & 216 & 376 & 57000 & 70 & 3 & 4 & 3 & 1 \\
\hline A20 & 1476300 & 40 & 59500 & 52 & 512 & 334 & 175000 & 16 & 3 & 3 & 4 & 2 \\
\hline A21 & 8864 & 33 & 0 & 0 & 400 & 219 & 58000 & 107 & 3 & 2 & 3 & 3 \\
\hline A22 & 30000 & 16 & 24035 & 17 & 244 & 99 & 60000 & 93 & 2 & 3 & 2 & 2 \\
\hline A23 & 298903 & 22 & 0 & 81 & 83 & 1508 & 550000 & 35 & 4 & 4 & 3 & 1 \\
\hline A24 & 795315 & 9 & 0 & 0 & 555 & 650 & 800000 & 155 & 3 & 3 & 3 & 2 \\
\hline
\end{tabular}

\section{Application And Findings}

During data analysis, CRITIC, TOPSIS, MOORA, and VIKOR methods were conducted in a hybrid way. Weights of the criteria that are thought to affect the level of danger in NHS where tourism activities are seen as a threat, were calculated by using the CRITIC method. Criterion weights are used as inputs for TOPSIS, MOORA, and VIKOR methods in which natural areas are ranked. The reason for using three different methods is to see the differences in the rankings and to examine the consistency among the methods. Finally, rankings were analyzed with the BORDA counting technique, and an integrated result was obtained. The application steps and formulations of these methods are included in the Supplementary File (SF).

Upon determining $r$ the alternatives and criteria, and collecting raw data, the analysis phase started. Techniques applied during the analysis process and the findings obtained are presented in detail below. Important steps of the techniques are presented and given in some tables in order not to create data complexity and repetition.

\subsection{Determination of Criterion Weights with CRITIC Method}


Determining the weights in multi-criteria problems is a critical step in the whole decision-making process. In MCDM methods, criterion weights are usually determined by subjective or objective techniques. Weighting with subjective techniques is related to the experience and knowledge of the decision-makers and the structure of the problem. Therefore, the results of subjective techniques may show bias. Moreover, objective weighting methods are recommended to ensure the reliability of the results (Kazan and Ozdemir 2014). In this study, CRITIC method was preferred as one of the objective weighting, in which the objective weight of each criterion depends on its standard deviation and correlation with other criteria. (Diakoulaki et al., 1995; Wang and Luo 2010).

For the CRITIC steps and formulations in the SF were followed. Standard deviation values and criteria weights calculated with the correlation matrix, showing the strength of the relationship between the criteria, are summarized in Table 4.

Table 4

Determination of criterion weights with CRITIC method

\begin{tabular}{|lllllllllllllll|}
\hline & C1 & C2 & C3 & C4 & C5 & C6 & C7 & C8 & C9 & C10 & C11 & C12 & SD & Ck \\
\hline C1 & 1,000 & $-0,229$ & $-0,700$ & $-0,355$ & $-0,890$ & 0,090 & $-0,059$ & $-0,183$ & $-0,110$ & $-0,137$ & $-0,149$ & 0,124 & 0,463 & 6,205 \\
\hline C2 & $-0,229$ & 1,000 & 0,472 & 0,191 & 0,175 & $-0,259$ & $-0,115$ & $-0,280$ & 0,203 & 0,255 & 0,231 & $-0,239$ & 0,376 & 3,801 \\
\hline C3 & $-0,700$ & 0,472 & 1,000 & 0,316 & 0,573 & $-0,055$ & $-0,188$ & 0,006 & 0,059 & 0,155 & $-0,020$ & $-0,157$ & 0,432 & 4,489 \\
\hline C4 & $-0,355$ & 0,191 & 0,316 & 1,000 & 0,329 & 0,270 & $-0,008$ & 0,002 & $-0,054$ & 0,134 & 0,297 & $-0,278$ & 0,350 & 3,621 \\
\hline C5 & $-0,890$ & 0,175 & 0,573 & 0,329 & 1,000 & 0,053 & 0,206 & 0,222 & 0,119 & $-0,005$ & 0,273 & $-0,269$ & 0,452 & 4,435 \\
\hline C6 & 0,090 & $-0,259$ & $-0,055$ & 0,270 & 0,053 & 1,000 & 0,180 & $-0,160$ & $-0,128$ & $-0,210$ & 0,174 & $-0,011$ & 0,334 & 3,883 \\
\hline C7 & $-0,059$ & $-0,115$ & $-0,188$ & $-0,008$ & 0,206 & 0,180 & 1,000 & 0,107 & 0,105 & $-0,036$ & 0,038 & $-0,057$ & 0,308 & 3,309 \\
\hline C8 & $-0,183$ & $-0,280$ & 0,006 & 0,002 & 0,222 & $-0,160$ & 0,107 & 1,000 & $-0,143$ & $-0,377$ & 0,359 & 0,252 & 0,369 & 4,104 \\
\hline C9 & $-0,110$ & 0,203 & 0,059 & $-0,054$ & 0,119 & $-0,128$ & 0,105 & $-0,143$ & 1,000 & 0,572 & 0,158 & $-0,659$ & 0,405 & 3,713 \\
\hline C10 & $-0,137$ & 0,255 & 0,155 & 0,134 & $-0,005$ & $-0,210$ & $-0,036$ & $-0,377$ & 0,572 & 1,000 & $-0,016$ & $-0,598$ & 0,421 & 4,288 \\
\hline C11 & $-0,149$ & 0,231 & $-0,020$ & 0,297 & 0,273 & 0,174 & 0,038 & 0,359 & 0,158 & $-0,016$ & 1,000 & $-0,231$ & 0,317 & 3,005 \\
\hline C12 & 0,124 & $-0,239$ & $-0,157$ & $-0,278$ & $-0,269$ & $-0,011$ & $-0,057$ & 0,252 & $-0,659$ & $-0,598$ & $-0,231$ & 1,000 & 0,432 & 4,871 \\
\hline Wi & 0,125 & 0,076 & 0,09 & 0,073 & 0,089 & 0,078 & 0,067 & 0,083 & 0,075 & 0,086 & 0,06 & 0,098 & & \\
\hline
\end{tabular}

When 12 criteria that are thought to have an impact on danger level of NHS are evaluated, the criteria of "Property (0,125)", "Tourism and visitation management $(0,098)$ " and "Assistance $(0,09)$ " come to the fore. On the other hand, the criteria with the lowest weight are "Overall assessment for threats (0.06)" and "Number of visitors (0.067)".

\subsection{Ranking of threat levels with TOPSIS and MOORA Methods}

Firstly, TOPSIS and MOORA methods were applied to rank the alternatives. TOPSIS is based on the fact that the alternatives have the Euclidean distance closest to the positive ideal solution and the farthest from the negative one (Tzeng and Huang 2011). MOORA is a ratio system in which an alternative on a target is compared with a denominator representing all alternatives related to that target (Kalibatas and Turskis 2008). The MOORA is more preferred in MCDM problems due to the simplicity of mathematical operations, short computation time, and reliability (Brauers and Zavadskas 2006). It has different applications such as ratio method, reference point approach, importance coefficient, multi-moora, full product. The MOORA Ratio method was used in this study.

Since the normalization and weighted normalization formulas used in both methods are the same, we deemed appropriate to present the results together. In this part, we first calculated the normalized decision matrix using SF-Equation 7, then obtained the weighted normalized decision matrix for TOPSIS and MOORA by using the weights. The ideal and negative ideal solution values used in the TOPSIS are also calculated by SF-Equations 8 and 9 (Table 5).

Table5. Weighted decision matrix with $V+V$ - scores 


\begin{tabular}{|c|c|c|c|c|c|c|c|c|c|c|c|c|}
\hline & $C 1$ & $C 2$ & $C 3$ & $C 4$ & C5 & c6 & $C 7$ & $C 8$ & C9 & $C 10$ & $C 11$ & C12 \\
\hline A1 & 0,003 & 0,012 & 0,000 & 0,000 & 0,008 & 0,003 & 0,014 & 0,001 & 0,011 & 0,020 & 0,011 & 0,028 \\
\hline A2 & 0,001 & 0,015 & 0,000 & 0,023 & 0,006 & 0,026 & 0,002 & 0,004 & 0,011 & 0,007 & 0,011 & 0,028 \\
\hline A3 & 0,000 & 0,011 & 0,001 & 0,000 & 0,003 & 0,003 & 0,001 & 0,017 & 0,017 & 0,020 & 0,011 & 0,019 \\
\hline A4 & 0,005 & 0,008 & 0,000 & 0,023 & 0,014 & 0,019 & 0,007 & 0,008 & 0,011 & 0,013 & 0,011 & 0,019 \\
\hline A5 & 0,000 & 0,022 & 0,014 & 0,015 & 0,005 & 0,005 & 0,003 & 0,013 & 0,022 & 0,020 & 0,011 & 0,019 \\
\hline A6 & 0,105 & 0,023 & 0,075 & 0,027 & 0,053 & 0,004 & 0,003 & 0,015 & 0,017 & 0,020 & 0,011 & 0,019 \\
\hline A7 & 0,003 & 0,019 & 0,000 & 0,002 & 0,009 & 0,012 & 0,021 & 0,011 & 0,011 & 0,013 & 0,011 & 0,028 \\
\hline A8 & 0,008 & 0,011 & 0,000 & 0,005 & 0,007 & 0,011 & 0,032 & 0,025 & 0,011 & 0,007 & 0,011 & 0,028 \\
\hline A9 & 0,000 & 0,020 & 0,020 & 0,026 & 0,011 & 0,003 & 0,017 & 0,014 & 0,011 & 0,020 & 0,011 & 0,019 \\
\hline A10 & 0,001 & 0,001 & 0,000 & 0,000 & 0,004 & 0,024 & 0,000 & 0,011 & 0,017 & 0,020 & 0,011 & 0,019 \\
\hline A11 & 0,000 & 0,005 & 0,005 & 0,013 & 0,010 & 0,004 & 0,003 & 0,064 & 0,011 & 0,007 & 0,015 & 0,028 \\
\hline A12 & 0,002 & 0,016 & 0,014 & 0,011 & 0,025 & 0,001 & 0,002 & 0,008 & 0,017 & 0,007 & 0,011 & 0,009 \\
\hline A13 & 0,066 & 0,013 & 0,004 & 0,032 & 0,054 & 0,014 & 0,021 & 0,027 & 0,017 & 0,020 & 0,015 & 0,009 \\
\hline A14 & 0,000 & 0,020 & 0,018 & 0,006 & 0,018 & 0,046 & 0,009 & 0,002 & 0,017 & 0,020 & 0,015 & 0,009 \\
\hline A15 & 0,005 & 0,020 & 0,010 & 0,009 & 0,006 & 0,001 & 0,000 & 0,001 & 0,011 & 0,020 & 0,011 & 0,019 \\
\hline A16 & 0,001 & 0,022 & 0,002 & 0,003 & 0,004 & 0,000 & 0,003 & 0,008 & 0,017 & 0,020 & 0,015 & 0,009 \\
\hline A17 & 0,001 & 0,010 & 0,004 & 0,008 & 0,016 & 0,021 & 0,042 & 0,003 & 0,022 & 0,020 & 0,011 & 0,009 \\
\hline A18 & 0,003 & 0,007 & 0,019 & 0,021 & 0,009 & 0,034 & 0,000 & 0,003 & 0,006 & 0,007 & 0,011 & 0,028 \\
\hline A19 & 0,001 & 0,022 & 0,028 & 0,012 & 0,004 & 0,003 & 0,001 & 0,003 & 0,017 & 0,026 & 0,011 & 0,009 \\
\hline A20 & 0,011 & 0,021 & 0,007 & 0,011 & 0,009 & 0,003 & 0,002 & 0,001 & 0,017 & 0,020 & 0,015 & 0,019 \\
\hline A21 & 0,000 & 0,017 & 0,000 & 0,005 & 0,007 & 0,002 & 0,001 & 0,005 & 0,017 & 0,013 & 0,011 & 0,028 \\
\hline A22 & 0,000 & 0,008 & 0,003 & 0,009 & 0,004 & 0,001 & 0,001 & 0,005 & 0,011 & 0,020 & 0,008 & 0,019 \\
\hline A23 & 0,002 & 0,012 & 0,000 & 0,018 & 0,001 & 0,012 & 0,006 & 0,002 & 0,022 & 0,026 & 0,011 & 0,009 \\
\hline A24 & 0,006 & 0,005 & 0,000 & 0,000 & 0,010 & 0,005 & 0,008 & 0,008 & 0,017 & 0,020 & 0,011 & 0,019 \\
\hline $\mathrm{V}+$ & 0,000 & 0,023 & 0,075 & 0,032 & 0,054 & 0,046 & 0,042 & 0,064 & 0,022 & 0,026 & 0,015 & 0,009 \\
\hline V- & 0,105 & 0,001 & 0,000 & 0,000 & 0,001 & 0,000 & 0,000 & 0,001 & 0,006 & 0,007 & 0,008 & 0,028 \\
\hline
\end{tabular}

In Table 6, the Euclidean distance and the closest distance to the ideal solution, and the farthest distance to the negative ideal solution were determined for TOPSIS (SF-Equations 10 and 11). To calculate the relative closeness 0 to the ideal solution, equation 12 is applied by using the ideal and negative ideal discrimination criteria and the ranking of the alternatives is presented. In the same table, the ranking created with MOORA is also seen. The maximum or minimum directional conditions of the criteria with SF-Equation 14 over the weighted normalized decision matrix values were calculated. Finally, values were calculated using SF-Equation 15 and presented in Table 6. 
Table 6

Sit, Si- and Ci, Yi TOPSIS and MOORA Rankings

\begin{tabular}{|llllllll|}
\hline & TOPSiS & & & & \multicolumn{3}{c|}{ MOORA } \\
\hline & S+ & S- & Ci & Rank & & Yi & Rank \\
\hline A1 & 0,126 & 0,104 & 0,452 & 21 & A1 & 0,049 & 24 \\
\hline A2 & 0,121 & 0,111 & 0,478 & 12 & A2 & 0,075 & 16 \\
\hline A3 & 0,123 & 0,108 & 0,467 & 16 & A3 & 0,064 & 20 \\
\hline A4 & 0,114 & 0,107 & 0,484 & 10 & A4 & 0,092 & 11 \\
\hline A5 & 0,111 & 0,112 & 0,503 & 6 & A5 & 0,112 & 7 \\
\hline A6 & 0,130 & 0,101 & 0,437 & 24 & A6 & 0,124 & 5 \\
\hline A7 & 0,117 & 0,108 & 0,480 & 11 & A7 & 0,079 & 15 \\
\hline A8 & 0,111 & 0,107 & 0,489 & 9 & A8 & 0,085 & 13 \\
\hline A9 & 0,101 & 0,115 & 0,534 & 3 & A9 & 0,134 & 4 \\
\hline A10 & 0,121 & 0,109 & 0,473 & 13 & A10 & 0,069 & 18 \\
\hline A11 & 0,108 & 0,124 & 0,535 & 2 & A11 & 0,109 & 8 \\
\hline A12 & 0,111 & 0,111 & 0,500 & 8 & A12 & 0,100 & 9 \\
\hline A13 & 0,111 & 0,086 & 0,437 & 23 & A13 & 0,141 & 3 \\
\hline A14 & 0,102 & 0,122 & 0,545 & 1 & A14 & 0,159 & 1 \\
\hline A15 & 0,123 & 0,104 & 0,458 & 17 & A15 & 0,064 & 19 \\
\hline A16 & 0,124 & 0,110 & 0,470 & 15 & A16 & 0,084 & 14 \\
\hline A17 & 0,108 & 0,119 & 0,525 & 4 & A17 & 0,146 & 2 \\
\hline A18 & 0,111 & 0,112 & 0,502 & 7 & A18 & 0,086 & 12 \\
\hline A19 & 0,111 & 0,114 & 0,506 & 5 & A19 & 0,116 & 6 \\
\hline A20 & 0,122 & 0,099 & 0,449 & 22 & A20 & 0,075 & 17 \\
\hline A21 & 0,128 & 0,107 & 0,457 & 19 & A21 & 0,050 & 22 \\
\hline A22 & 0,127 & 0,107 & 0,458 & 18 & A22 & 0,050 & 23 \\
\hline A23 & 0,123 & 0,110 & 0,473 & 14 & A23 & 0,098 & 10 \\
\hline A24 & 0,123 & 0,102 & 0,454 & 20 & A24 & 0,058 & 21 \\
\hline
\end{tabular}

As can be seen from Table 7, the top three NHS with high levels of danger according to the TOPSIS method are "National Park of Lake Malawi", "Great Rift Valley Lake System (Kenya)" and "Historic Sanctuary of Machu Picchu", respectively. On the other hand, areas of less significant concern are "Serengeti National Park", "Lake Baikal" and "Galápagos Islands", respectively.

According to the MOORA Ratio method, "National Park of Lake Malawi", "National Park of Phong Nha-Ke Bang" and "Lake Baikal" are the top three NHS with a high danger level. Less endangered areas are the "Atlantic Forest Southeast Reserves", the "Vredefort Dome" and the "Sinharaja Forest Reserve".

\subsection{Ranking the threat levels with the VIKOR Method}

The VIKOR method, proposed by Opricovic in 1998, is based on the compromise solution approach in complex decision-making situations with disproportionate and contradictory criteria, where a solution that meets all criteria cannot be found at the same time (Opricovic 1998; Opricovic and Tzeng 2004). The ${ }^{L_{p}}$ metric is used to find the best solution in the VIKOR technique (Shojaei et al. 2018): 


$$
L_{p j}=\left\{\sum_{i=1}^{n}\left[\frac{w_{i}\left(f_{i}^{*}-f_{i j}\right)}{\left(f_{i}^{*}-f_{i}^{-}\right)}\right]^{p}\right\}^{1 / p} ; 0 \leq p \leq \infty ; j=1,2,3, \ldots . j
$$

VIKOR uses rank measures $\mathrm{L}_{1 j}=\mathrm{S}_{j}$ andL $\mathrm{L}_{\infty \mathrm{j}}=\mathrm{R}_{j} \cdot w_{i}$ is the weight that indicates the relative importance of the criterion. $f_{i j}$ is the value of alternative $i$ according to the $\mathrm{j}$ criterion. $\left(f_{i}^{*}\right)$ and $\left(f_{i}^{-}\right)$indicate the best and worst ideal solution. Here, $\min _{j} S_{J}$ indicates maximum group utility, while $\min _{j} R_{J}$ is used for minimum individual regret.

The best and worst values for each criterion were calculated with equation 16 by using Table 3 . Then equations 17 and 18 were used to calculate the Si and Ri values. For VIKOR, the Qi values were calculated in the last step and, accordingly, the ranking of the alternatives was presented (Table 7).

Table7. VIKOR rank

\begin{tabular}{|c|c|c|c|c|}
\hline & $S i$ & $R i$ & $Q i$ & Rank \\
\hline $\mathrm{A} 1$ & 0,691 & 0,098 & 0,740 & 24 \\
\hline $\mathrm{A} 2$ & 0,661 & 0,098 & 0,691 & 20 \\
\hline A3 & 0,625 & 0,089 & 0,546 & 13 \\
\hline A4 & 0,595 & 0,090 & 0,506 & 12 \\
\hline A5 & 0,504 & 0,083 & 0,284 & 6 \\
\hline A6 & 0,468 & 0,125 & 0,632 & 17 \\
\hline A7 & 0,648 & 0,098 & 0,670 & 19 \\
\hline A8 & 0,672 & 0,098 & 0,708 & 21 \\
\hline A9 & 0,499 & 0,073 & 0,183 & 3 \\
\hline A10 & 0,630 & 0,090 & 0,562 & 14 \\
\hline A11 & 0,631 & 0,098 & 0,641 & 18 \\
\hline A12 & 0,553 & 0,086 & 0,397 & 10 \\
\hline A13 & 0,388 & 0,085 & 0,118 & 2 \\
\hline A14 & 0,389 & 0,082 & 0,086 & 1 \\
\hline A15 & 0,614 & 0,083 & 0,469 & 11 \\
\hline A16 & 0,508 & 0,087 & 0,334 & 8 \\
\hline A17 & 0,434 & 0,086 & 0,200 & 4 \\
\hline A18 & 0,682 & 0,098 & 0,725 & 23 \\
\hline A19 & 0,465 & 0,085 & 0,243 & 5 \\
\hline A20 & 0,549 & 0,083 & 0,360 & 9 \\
\hline A21 & 0,680 & 0,098 & 0,721 & 22 \\
\hline A22 & 0,683 & 0,087 & 0,617 & 16 \\
\hline A23 & 0,481 & 0,090 & 0,317 & 7 \\
\hline A24 & 0,638 & 0,090 & 0,577 & 15 \\
\hline
\end{tabular}

In the VIKOR ranking, "Lake Malawi National Park", "Lake Baikal” and "Historic Sanctuary of Machu Picchu” took the first three places, while "Atlantic Forest Southeast Reserves", "Rainforest of the Atsinanana” and "Sinharaja Forest Reserve" are listed last. 


\subsection{Obtaining the Final Ranking by BORDA Count Method}

In the rankings of TOPSIS, MOORA, and VIKOR methods, the alternatives are ranked close to each other. In this study aim was to create a final ranking by combining the rankings of these methods with the BORDA Counting technique. It is common to use more than one technique together in studies using MCDM as there is the attempt to obtain comparisons or consistency between methods. Since analyses made with different techniques may yield different results, some methods for evaluation of these different results together have been developed. Thus, BORDA Counting technique offers the opportunity to combine rankings created with more than one technique into a single ranking (Wu 2011). It accepts each technique with equal importance for classification performance, while also offering convenience in terms of applicability (Akyuz and Salih 2017). In the ranking of the alternatives, the best alternative is $\mathrm{m}-1$, the second-best alternative is $\mathrm{m}$ 2 , and the worst alternative is scored as 0 . By adding new values, BORDA

count score is obtained and sorting is performed (Lansdowne and Woodward 1996). In the

Equation below, $m$ is the total number of alternatives, for $r_{i k} \mathrm{k}$ is criterion and $\mathrm{i}$ refers to the rank of the alternative.

$$
b_{i}=\sum_{k=1}^{n}\left(m-r_{i k}\right)
$$

The final ranking using BORDA is shown in Table 8.

Table8. Rankings of the alternatives via three methods 


\begin{tabular}{|c|c|c|c|c|}
\hline & TOPSIS & MOORA & VIKOR & BORDA \\
\hline $\mathrm{A} 1$ & 21 & 24 & 21 & 24 \\
\hline $\mathrm{A} 2$ & 12 & 11 & 11 & 18 \\
\hline A3 & 16 & 20 & 17 & 20 \\
\hline A4 & 10 & 12 & 14 & 10 \\
\hline A5 & 6 & 7 & 5 & 5 \\
\hline A6 & 24 & 6 & 23 & 16 \\
\hline A7 & 11 & 15 & 22 & 14 \\
\hline A8 & 9 & 14 & 24 & 13 \\
\hline A9 & 3 & 4 & 3 & 2 \\
\hline A10 & 13 & 18 & 18 & 15 \\
\hline A11 & 2 & 5 & 10 & 7 \\
\hline A12 & 8 & 13 & 13 & 6 \\
\hline A13 & 23 & 2 & 2 & 8 \\
\hline A14 & 1 & 1 & 1 & 1 \\
\hline A15 & 17 & 19 & 12 & 17 \\
\hline A16 & 15 & 16 & 9 & 11 \\
\hline A17 & 4 & 3 & 4 & 3 \\
\hline A18 & 7 & 10 & 15 & 12 \\
\hline A19 & 5 & 8 & 7 & 4 \\
\hline A20 & 22 & 17 & 8 & 19 \\
\hline A21 & 19 & 22 & 19 & 23 \\
\hline A22 & 18 & 21 & 16 & 22 \\
\hline A23 & 14 & 9 & 6 & 9 \\
\hline A24 & 20 & 23 & 20 & 21 \\
\hline
\end{tabular}

According to the final ranking, the sites with the highest level of danger are "Lake Malawi National Park", "Historic Sanctuary of Machu Picchu" and "National Park of Phong Nha-Ke Bang". "Atlantic Forest Southeast Reserves", "Sinharaja Forest Reserve" and "Vredefort Dome” took the last place among a total of 24 sites. Detailed findings on the most critically threatened sites and their current status are presented as SF.

\section{Conclusion}

Aim of this study was to determine the level of danger created by tourism activities in natural areas, which are at the level of significant concern in the UNESCO WHL and where tourism activities are perceived as a threat. 24 NHS were analyzed by MCDM methods using the following criteria: visitor numbers, number of accommodation facilities, impact of tourism, impact of tourism on infrastructure, tourism and visitor management, size of the area, species number in flora and fauna, year of registration in the UNESCO list, financial aids, report score, and general assessment of threats. Findings of TOPSIS, MOORA, and VIKOR techniques were re-examined in the BORDA method and final ranking was obtained. According to the results of the study, the NHS with the highest level of danger are "Lake Malawi National Park", "Historic Sanctuary of Machu Picchu" and "National Park of Phong Nha-Ke Bang ", while "Atlantic Forest Southeast Reserves", "Sinharaja Forest Reserve" and "Vredefort Dome" were found to be the least affected sites.

When the current situation of the affected natural areas is examined, the effects of tourism can be clearly seen. In recent years, various threats have increased in Lake Malawi, primarily due to the increase in the human population related to tourism activities in the region, oil resource potential, changing climate and implementation of altered management plan. Therefore, there is a necessity for monitoring 
systems to assess threats' trends and status, while the heritage values remain mostly intact. While tourism facilities around Lake Malawi make efforts to minimize the environmental impacts, the increase in the tourist numbers and permanent residents cannot be prevented from posing a pollution threat. Other impacts of tourism contain increased degradation of nearshore fish sets due to boat noise and scuba divers, as well as the loss of local culture and tradition (Harding et al. 2018).

Since its inclusion in the WHL, Machu Picchu has witnessed activities such as deforestation and commercial plant gathering, poor waste management, poaching, and the prevalence of agricultural use due to the absence of open land tenure regulations for the development of tourism. In addition, these events cause the deterioration of the ecosystem in the region through water pollution from both urban waste and agriculture.

For Phong Nha-Ke Bang, the threat of increased over-reliance on income from tourism remains. In addition, a distinct benefit-sharing in local communities is not adopted yet. However, while the conservation of caves has been consistently successful, the report about Reactive Monitoring Mission in 2018 states that waste product accumulated in Paradise Cave draws mice and rats posing a considerable menace to the cave (UNESCO and IUCN 2018). Lately, activities that are of great interest to visitors, such as caving and kayaking experiences, mud baths, an expanding zip-line system, and the expansion of a water playground in Nuoc Mooc Eco cave, indicate that tourism poses a threat.

\subsection{Managerial Implications for NHS}

Understanding the responsibilities of the World Heritage Convention is fundamental for decision-making and policy. Operational Guidelines have a major impact on tourism management and provide operable guidance on responsibilities. World Heritage network tenders unique chances, and it has a great number of beneficial resources for tourism managers (Pedersen 2002).

Environmental protection and tourism development in key heritage sites often involve multiple stakeholders. Topics such as WHS assignment, marketing, interpretation, revenue generation and visitor management are often controversial and complex. The responsibility is vital in managing these appropriately and ensuring the resources are not harmed by visitors, environmental conditions, or conflicts of interest.

The clearest way to balance conservation use activities is to include them effectively in management plans and recognizing management practices that can be used to maximize or control the benefits. Thus, it is important to integrate WHS management into land management and tourism plans at local, regional, and national levels. Indeed, Balmford et al. (2001) states that future conflicts between development and conservation cannot be easily avoided, and that the conservation of reserves in regions with high population will become increasingly difficult.

For the benefit of both heritage sites and tourism industry, joint planning of conservation and tourism is inevitable, as tourism itself represents a remarkable threat for conversation in some regions. Additional funds for the management and monitoring of sites and visitors can be provided. Besides UNESCO donations, tourism tax or government funds may play a key role in supporting the regional tourism industry.

Although usually quite delicate. the effects caused by tourists are generally avoidable (e.g., visitors may be requested not to feed animals). On the other hand, it may be difficult to determine the cause-effect relationships of tourism effects. Garbage may be disposed of by residents, not tourists, or water pollution may stem from sources other than hotels, coastal areas may suffer from natural events rather than tourism, hunting by locals may explain the declining amount of biodiversity. Therefore, it is recommended to consider such effects when preparing status reports for heritage sites.

While visitor capacity is a particularly serious issue for natural areas in terms of sustainability, solutions for decreasing numbers in the area may not always be impressive. Since effects are related to complex socio-environmental parameters and developmental patterns, it is important to understand the interrelationships that may facilitate locals in hosting tourists or cause strong opposition to their presence.

Relatively all WHS are associated with their 'local communities'. Therefore, for tourism activities, visitor areas should be carefully planned and WHS visitors should not interfere with the daily lives of local people or their ties with WHS (ICOMOS 1999). The authorities are advised to adopt a prevalent policy aiming to give natural and cultural heritage a function in daily life of residents and to integrate heritage conservation into comprehensive planning programs (Jimura 2018).

\subsection{Limitations and Recommendations for Further Research}

As with many studies, this study also has limitations. The limitations of the study are; (1) the selection of sites where tourism is seen as dangerous for the NHS and (2) the conservation outlook level is seen as significant concern, (3) the use of secondary data, and (4) the 
selection of MCDM techniques for the method. According to these limitations the authors offer some suggestions for future studies. Firstly, the authors had difficulty choosing variables to study tourism effects on sites, despite using UNESCO data. Therefore, determining the variables for a more detailed examination of tourism effects in future studies and considering the studies in a wider framework (other effects besides tourism) will contribute to the literature. Secondly, methodological triangulation (longitudinal, cross-sectional, and mixed patterns) can be recommended to explain the subject in more detail, as MCDM techniques cannot explain the variable relations in an interpretive sense. Lastly, with the approach adopted in this study, the impact of tourism on cultural heritage sites can be evaluated.

\section{Declarations}

Ethical approval: All authors declare that they have no afliations with or involvement in any organization or entity with any fnancial interest or non-fnancial interest in the subject matter or materials discussed in this manuscript.

Author Contributions: All authors contributed to the study conception and design. Material preparation, data collection and analysis were performed by first and second authors, also they wrote the first draft of the manuscript. The all methos sections reviewed and controlled by corresponded author. All authors commented on previous versions of the manuscript. All authors read and approved the final manuscript.

Confict of interest: The authors declare that they have no confict of interest.

\section{References}

1. Akyüz G, Salih A (2017) Çok kriterli karar verme teknikleriyle tedarikçi performansı değerlendirmede toplamsal bir yaklaşım. Yönetim ve Ekon Araştırmaları Derg 15:28-46

2. Badola R, Hussain SA, Dobriyal P, et al (2018) Institutional arrangements for managing tourism in the Indian Himalayan protected areas. Tour Manag 66:1-12

3. Balmford A, Moore JL, Brooks T, et al (2001) Conservation conflicts across Africa. Science (80- ) 291:2616-2619

4. Bawa KS, Dayanandan S (1997) Socioeconomic factors and tropical deforestation. Nat 386:562-563

5. Bello FG, Carr N, Lovelock B (2016) Community participation framework for protected area-based tourism planning. Tour Plan Dev $13: 469-485$

6. Bibby CJ (1994) Recent past and future extinctions in birds. Philos Trans R Soc London Ser B Biol Sci 344:35-40

7. Bolla G (2005) Episodes of a painstaking gestation. In: Batisse M, Bolla G (eds) The invention of 'world heritage'. History Papers. UNESCO action as seen by protagonists and witnesses. Association of Former UNESCO Staff Members (AFUS), Paris

8. Brashares JS, Arcese P, Sam MK (2001) Human demography and reserve size predict wildlife extinction in West Africa. Proc R Soc London Ser B Biol Sci 268:2473-2478

9. Brauers WK, Zavadskas EK (2006) The MOORA method and its application to privatization in a transition economy. Control Cybern $35: 445-469$

10. Brooks TM, Mittermeier RA, Mittermeier CG, et al (2002) Habitat loss and extinction in the hotspots of biodiversity. Conserv Biol 16:909-923

11. Bryce D, Curran R, O'Gorman K, Taheri B (2015) Visitors' engagement and authenticity: Japanese heritage consumption. Tour Manag 46:571-581

12. Buckley R (2018) Tourism and natural World Heritage: A complicated relationship. J Travel Res 57:563-578

13. Buckley R (2004) The effects of World Heritage listing on tourism to Australian national parks. J Sustain Tour 12:70-84

14. Buckley R (2012) Sustainable tourism: Research and reality. Ann Tour Res 39:528-546

15. Cameron C (2013) Keynote Speech: 'Forty Years from the Birth of the Convention”.' In: Celebrating 40 years of the World Heritage Convention Proceedings. Kyoto, pp 26-33

16. Castro G, Locker I (2000) Mapping conservation investments: an assessment of biodiversity funding in Latin America and the Caribbean. Washington, D.C.

17. Cellini R (2011) Is UNESCO recognition effective in fostering tourism? A comment on Yang, Lin and Han. Tour Manag 32:452-454

18. Cheung KS, Li L-H (2019) Understanding visitor-resident relations in overtourism: Developing resilience for sustainable tourism. J Sustain Tour 27:1197-1216

19. Crouch GI (2011) Destination competitiveness: An analysis of determinant attributes. J Travel Res 50:27-45 
20. Cuccia T, Guccio C, Rizzo I (2016) The effects of UNESCO World Heritage List inscription on tourism destinations performance in Italian regions. Econ Model 53:494-508

21. De Ascaniis S, Gravari-Barbas M, Cantoni L (2018) Tourism Management at UNESCO World Heritage Sites. Università della Svizzera italiana, Lugano

22. de Oliveira Silva AW, Castro CF, Campos HL (2005) Impacts of ecotourism on the bog of Serra Negra-Bezerros/PE. Soc Nat 1:767-771

23. Demir S (2019) DETERMINING SUITABLE ECOTOURISM AREAS IN PROTECTED WATERSHED AREA THROUGH VISIBILITY ANALYSIS. J Environ Prot Ecol 20:214-223

24. Diakoulaki D, Mavrotas G, Papayannakis L (1995) Determining objective weights in multiple criteria problems: The critic method. Comput Oper Res 22:763-770

25. Dodds R, Butler R (2019) The phenomena of overtourism: A review. Int J Tour Cities 5:519-528

26. Formica S, Uysal M (2006) Destination attractiveness based on supply and demand evaluations: An analytical framework. J Travel Res 44:418-430

27. Frey BS, Steiner L (2011) World Heritage List: does it make sense? Int J Cult Policy 17:555-573

28. Fyall A, Rakic T (2006) The future market for World Heritage sites. In: Leask A, Fyall A (eds) Managing world heritage sites. Elsevier Ltd, London, pp 185-202

29. Hall CM (2008) Tourism planning: Policies, processes and relationships, 2. Pearson Education, London

30. Hansen AJ, DeFries R (2007) Ecological mechanisms linking protected areas to surrounding lands. Ecol Appl 17:974-988

31. Hansen MC, Potapov P V, Moore R, et al (2013) High-resolution global maps of 21st-century forest cover change. Science 342:850-853

32. Haraldsson H V, Ólafsdóttir R (2018) Evolution of tourism in natural destinations and dynamic sustainable thresholds over time. Sustainability 10:4788

33. Harding HR, Gordon TAC, Hsuan RE, et al (2018) Fish in habitats with higher motorboat disturbance show reduced sensitivity to motorboat noise. Biol Lett 14:20180441

34. Hategekimana Y, Yu LJ, Nie YP, et al (2018) Integration of multi-parametric fuzzy analytic hierarchy process and GIS along the UNESCO World Heritage: a flood hazard index, Mombasa County, Kenya. Nat HAZARDS 92:1137-1153. https://doi.org/10.1007/s11069-0183244-9

35. Huang C-H, Tsaur J-R, Yang C-H (2012) Does world heritage list really induce more tourists? Evidence from Macau. Tour Manag 33:1450-1457

36. Ibisch PL, Hoffmann MT, Kreft S, et al (2016) A global map of roadless areas and their conservation status. Science 354:1423-1427

37. ICOMOS (1999) INTERNATIONAL CULTURAL TOURISM CHARTER Managing Tourism at Places of Heritage Significance. https://www.icomos.org/charters/tourism_e.pdf

38. IUCN (2021) Natural sites. https://www.iucn.org/theme/world-heritage/natural-sites

39. Jimura T (2018) World Heritage Sites: Tourism, local communities and conservation activities. CABI

40. Jinshi F (2014) Tourism to the Mogao Grottoes: Overview of Conservation Challenges and Countermeasures. In: Agnew N, Demas M (eds) Extended abstracts of the International Colloquium Visitor management and carrying capacity at World heritage sites in China. Icomos Open Archive, Dunhuang, pp 12-19

41. Kalibatas D, Turskis Z (2008) Multicriteria evaluation of inner climate by using MOORA method. Inf Technol Control 37:79-83

42. Kazan H, Ozdemir O (2014) Financial performance assessment of large scale conglomerates via TOPSIS and CRITIC methods. Int J Manag Sustain 3:203-224

43. Koichi K, Cottrell A, Sangha KK, Gordon IJ (2013) What determines the acceptability of wildlife control methods? A case of feral pig management in the Wet Tropics World Heritage Area, Australia. Hum Dimens Wildl 18:97-108

44. Kozak M (2013) Sustainable Tourism Concepts-Applications. Detay Publishing, Ankara

45. Kuncova M, Tuckova Z, Vaculcikova Z (2018) The Tourism Infrastructure in the Czech Regions - Multi-Criteria Comparison. Vis. 2020 Sustain. Econ. Dev. Appl. Innov. Manag. 3336-3344

46. Lansdowne ZF, Woodward BS (1996) Applying the Borda ranking method. Air Force J Logist 20:27-29

47. Lucrezi S, Milanese M, Markantonatou V, et al (2017) Scuba diving tourism systems and sustainability: Perceptions by the scuba diving industry in two Marine Protected Areas. Tour Manag 59:385-403

48. Marcotte P, Bourdeau L (2012) Is the World Heritage label used as a promotional argument for sustainable tourism? J Cult Herit Manag Sustain Dev 2:80-91

Page $17 / 20$ 
49. Mardani A, Jusoh A, Nor K, et al (2015) Multiple criteria decision-making techniques and their applications-a review of the literature from 2000 to 2014. Econ Res istraživanja 28:516-571

50. Matsuura K (2007) Foreword. In: Labadi S, Bandarin F (eds) World heritage - challenges for the Millennium. UNESCO World Heritage Centre, Paris

51. McNeely JA, Ness G (1996) People, parks, and biodiversity: is-sues in population-environment dynamics. In: Dompka V (ed) Human population, biodiversity and protected areas: science and policy issues. American Association for the Advancement of Science, Washington, D.C., pp 19-70

52. Meskell L (2011) From Paris to Pontdrift: UNESCO meetings, Mapungubwe and mining. South African Archaeol Bull 66:149-156

53. Noss RF (1983) A regional landscape approach to maintain diversity. Bioscience 33:700-706

54. Opricovic S (1998) Multicriteria optimization of civil engineering systems. Fac Civ Eng Belgrade 2:5-21

55. Opricovic S, Tzeng G-H (2004) Compromise solution by MCDM methods: A comparative analysis of VIKOR and TOPSIS. Eur J Oper Res 156:445-455

56. Parks SA, Harcourt AH (2002) Reserve size, local human density, and mammalian extinctions in US protected areas. Conserv Biol 16:800-808

57. Patuelli R, Mussoni M, Candela G (2016) The effects of World Heritage Sites on domestic tourism: a spatial interaction model for Italy. In: Spatial Econometric Interaction Modelling. Springer, pp 281-315

58. Pedersen A (2002) Managing Tourism at World Heritage Sites: a Practical Manual for World Heritage Site Managers. UNESCO World Heritage Centre, Paris

59. Rocchi L, Cortina C, Paolotti L, Boggia A (2020) Recreation vs conservation in Natura 2000 sites: A spatial multicriteria approach analysis. Land use policy 99:105094

60. Rodríguez-Rodríguez D (2012) Littering in protected areas: a conservation and management challenge-a case study from the Autonomous Region of Madrid, Spain. J Sustain Tour 20:1011-1024

61. Semeraro T, Mastroleo G, Aretano R, et al (2016) GIS Fuzzy Expert System for the assessment of ecosystems vulnerability to fire in managing Mediterranean natural protected areas. J Environ Manage 168:94-103. https://doi.org/10.1016/j.jenvman.2015.11.053

62. Seraphin H, Sheeran P, Pilato M (2018) Over-tourism and the fall of Venice as a destination. J Destin Mark Manag 9:374-376

63. Shojaei P, Haeri SAS, Mohammadi S (2018) Airports evaluation and ranking model using Taguchi loss function, best-worst method and VIKOR technique. J Air Transp Manag 68:4-13

64. Slatyer RO (1983) The origin and evolution of the World Heritage Convention. Ambio 138-140

65. Spenceley A (2018) Sustainable tourism certification in the African hotel sector. Tour Rev 74:179-193

66. Stohlgren TJ, Schnase JL (2006) Risk analysis for biological hazards: what we need to know about invasive species. Risk Anal An Int J 26:163-173

67. Strasser P (2002) "Putting Reform Into Action"-Thirty Years of the World Heritage Convention: How to Reform a Convention without Changing Its Regulations. Int J Cult Prop 11:215-266

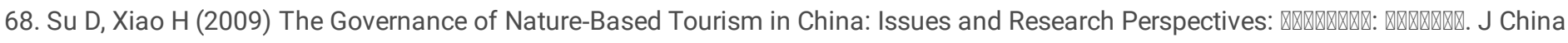
Tour Res 5:318-338

69. Su Y-W, Lin H-L (2014) Analysis of international tourist arrivals worldwide: The role of world heritage sites. Tour Manag 40:46-58

70. Trombulak SC, Frissell CA (2000) Review of ecological effects of roads on terrestrial and aquatic communities. Conserv Biol 14:18-30

71. Tverijonaite E, Ólafsdóttir R, Thorsteinsson T (2018) Accessibility of protected areas and visitor behaviour: A case study from Iceland. J outdoor Recreat Tour 24:1-10

72. Tzeng G-H, Huang J-J (2011) Multiple attribute decision making: methods and applications. CRC press

73. UNESCO (2021a) States Parties Ratification Status. https://whc.unesco.org/en/statesparties/

74. UNESCO (2021b) World heritage list: The criteria for selection. https://whc.unesco.org/en/criteria/

75. UNESCO (2021c) The UNESCO World Heritage and Sustainable Tourism Programme. https://whc.unesco.org/en/tourism/

76. UNESCO, IUCN (2018) Reactive Monitoring Mission Report Phong Nha-Ke Bang National Park (Viet Nam). Gland, Switzerland and Paris, France

77. Valagussa A, Frattini P, Crosta G, et al (2021) Multi-risk analysis on European cultural and natural UNESCO heritage sites. Nat HAZARDS 105:2659-2676. https://doi.org/10.1007/s11069-020-04417-7

78. Wall G (2020) From carrying capacity to overtourism: a perspective article. 75:212-215. https://doi.org/10.1108/TR-08-2019-0356 
79. Wang Y-M, Luo Y (2010) Integration of correlations with standard deviations for determining attribute weights in multiple attribute decision making. Math Comput Model 51:1-12

80. Wang Z, Du X (2016) Monitoring Natural World Heritage Sites: optimization of the monitoring system in Bogda with GIS-based multicriteria decision analysis. Environ Monit Assess 188:. https://doi.org/10.1007/s10661-016-5391-3

81. WHC (2021) World Heritage List. https://whc.unesco.org/en/list/

82. Wilcove DS, May RM (1986) Endangered species: The fate of the California condor. Nature 319:16

83. Wu W-W (2011) Beyond Travel \& Tourism competitiveness ranking using DEA, GST, ANN and Borda count. Expert Syst Appl 38:1297412982

84. Xu H, Cui Q, Sofield T, Li FMS (2014) Attaining harmony: Understanding the relationship between ecotourism and protected areas in China. J Sustain Tour 22:1131-1150

85. Yang C-H, Lin H-L, Han C-C (2010) Analysis of international tourist arrivals in China: The role of World Heritage Sites. Tour Manag 31:827-837

86. Yang C-H, Lin H-Y (2014) Revisiting the relationship between World Heritage Sites and tourism. Tour Econ 20:73-86

\section{Figures}

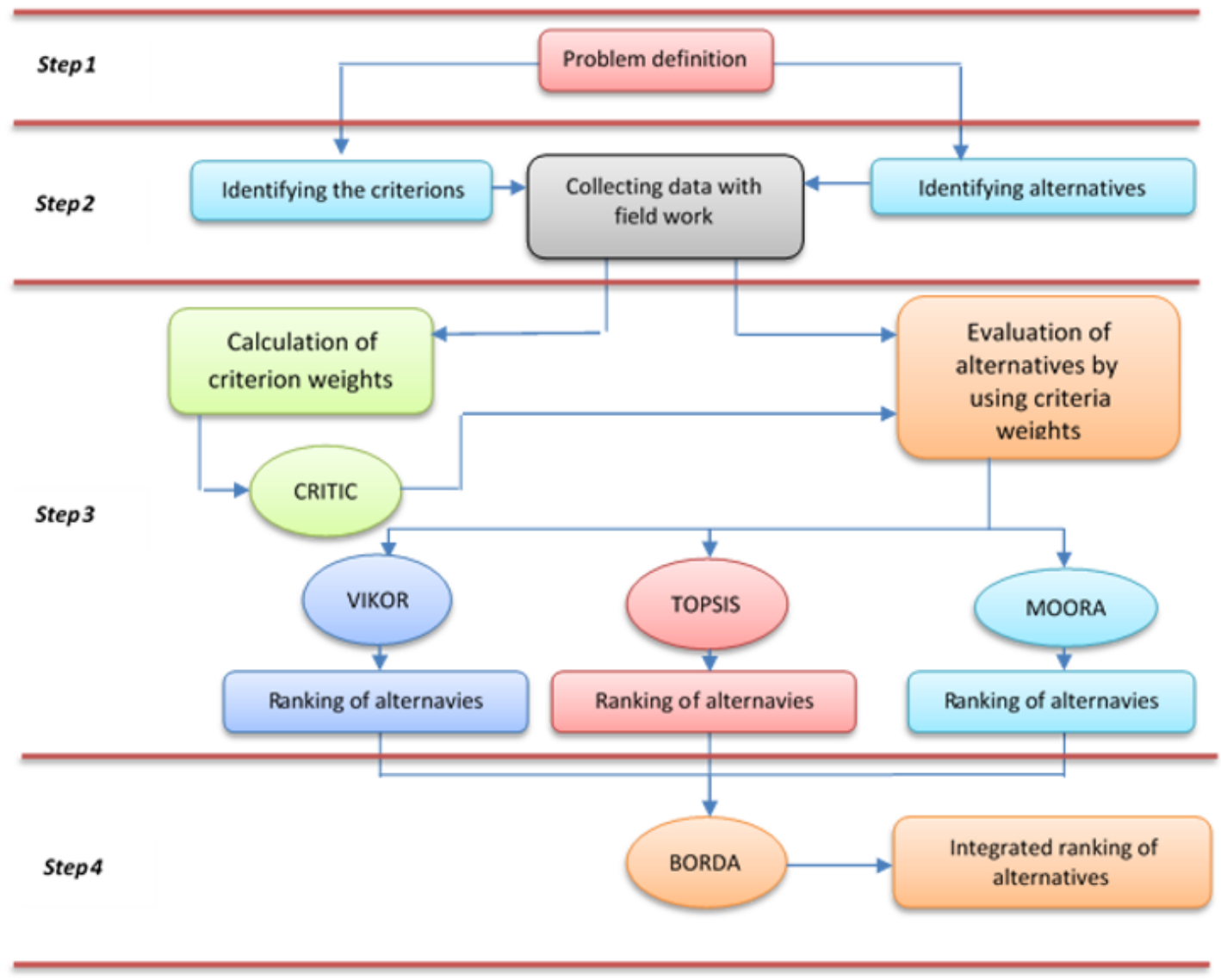

\section{Figure 1}

Research process chart

\section{Supplementary Files}

This is a list of supplementary files associated with this preprint. Click to download.

- MCDMformulas.docx 
- NHSCases.docx

Page 20/20 